\title{
吉井川上流域における鉄笑流しと濁水紛争
}

德 安 浩 明

\begin{tabular}{|c|c|}
\hline I はじめに & 行地点の分布 \\
\hline II 吉井川上流域の地理的性格と鑢製鉄 & IV 濁水紛争よりみた鉄穴流し稼行地点の \\
\hline （1）吉井川上流域の地理的性格 & 分布 \\
\hline （2）鑢製鉄・鉄穴流しの稼行 & （1）鉄穴流しの存在意義 \\
\hline III 地形・地質条件よりみた鉄穴流し稼行 & （2）濁水紛争よりみた鉄穴流し稼行地点 \\
\hline 地点の分布 & の分布 \\
\hline （1） 鉄穴跡地の地形的特色 & $\mathrm{V}$ む す び \\
\hline （2）地形・地質条件よりみた鉄穴流し稼 & \\
\hline
\end{tabular}

キーワード : 鉄穴流し, 鉄穴流し跡地, 鑪製鉄, 濁水紛争, 近世, 吉井川

I はじめに

わが国の製鉄は，明治期の洋式製鉄法導入ま で，鑪とよばれる砂鉄製錬法を中心として行 われてきた。原料である砂鉄は, 花崗岩類の風 化層を人為的に掘り崩したのち水路に流し込み, 比重の違いを利用して水路に沈殿させる方法で 採取された。この砂鉄採取法が, 近世初頭には 中国山地の広い範囲に普及していたとされる鉄 穴流しである。冬季を中心に, 農間余業として 稼行されることの多かった鉄穴流しは，近世の 中国山地で生活する農民に, 貴重な就業機会を
提供した。この点については, 武井博明や片田 朋子, 田村啓介, 佃雅文らが, 詳細な史料の分 析から考察している。

一方，鉄穴流しは，大量の花崗岩類の風化土 を必要としたため, 大規模な地形改変を引き起 こした。その結果, 鉄穴流しにともなって排出 された大量の土砂は, 下流地域に水害・水質污 濁などの悪影響をもたらすことが多かった。そ のため鉄穴流しが行われると，上流の稼行地域 と下流地域との間には,「濁水紛争」とよばれ る争論が繰り返し発生したのである。

鉄穴流しに関しては，地理学ではそれの引き

1）土井作治「松江藩の鉄山政策と製鉄技術」（たたら研究会編『日本製鉄史論集』，同会，1983）415頁。

2）鉄穴流しの構造については，以下の文献において詳しく述べられている。(1)庄司久孝「近世以降，たたら（鑪）による 中国山地の開拓」, 岡山大学法文学部学術紀要 3，1954，61一65頁。(2)石塚尊俊『民俗民芸双書70 鑪と鍛冶』, 岩崎美術 社，1972，101-104頁など。

3）(1)武井博明「幕末期広島藩における一鉄穴経営」, 芸備地方史研究47，1963，14一27頁。(2)武井博明「近世後期におけ る鉄穴経営と村落構造」, 史学研究101, 1967, 19-37頁。

4）片田朋子「19世紀における鉄穴の経営実態とその変遷一芸州高田郡粟屋村における民営鉄穴から藩営鉄穴への移行一」, たたら研究，1965，18一30頁。

5）田村啓介「幕末期における砂鉄採取業についての一考察一備中国阿賀郡井原村を事例として一」, 岡山県立博物館研究 報告 4 ，1983，1-19頁。

6）佃 雅文「備後東城川流域における鉄穴流し」，瀬戸内海地域史研究 3，1991，205一234頁。

7）岩永 実「たたら製鉄の生産構造」(多田文男・石田龍次郎編『現代地理学講座 7 生産の地理」, 河出書房, 1956) 286-288頁。 
起こす地形改変が主たる研究課題とされてきた。 赤木祥彦と貞方昇は, 空中写真の判読と現地で の地形調査にもとづいて，鉄穴流しによって掘 り崩された土地である鉄穴流し跡地（以下, 鉄 穴跡地と略す）が中国山地の広い範囲にわたっ て分布することを確認した。そのうえで，鉄穴 流しの行われる地形・地質条件や，鉄穴跡地の 具体的な位置とその面積, および地形改変土量 などが明らかにされた。たしかに，鉄穴流しの 稼行地点である「鉄穴場」の分布について，そ の地理的条件を検討することは，鉄穴流しの研 究における基礎的かつ重要なテーマである。し かし，地形・地質といった自然条件のみで鉄穴 場の分布は説明できるのであろうか。

濁水紛争の発生が鉄穴流しの稼行制限をもた らすことは, 藤井駿 ・加藤耕作, 宗森英之, 加 原耕作，安藤精一らによって明らかにされてい る。したがって，濁水紛争が鉄穴場の分布に影 響を与えることは，十分に考えられるのである。 鉄穴場の分布を規定した要因について，地形・ 地質などの自然条件と濁水紛争のような人文条 件の両面から検討することが必要である。

研究の対象地域として, 岡山県の吉井川上流 域をとりあげる（第 1 図）。近世の吉井川上流域 はおおむね美作国津山藩領，あるいは他領の預 り地などに，中流域は津山藩，下流域は備前国 岡山藩に属していた。この支配関係の相違は, 濁水紛争をより深刻化させたかと思われる。そ

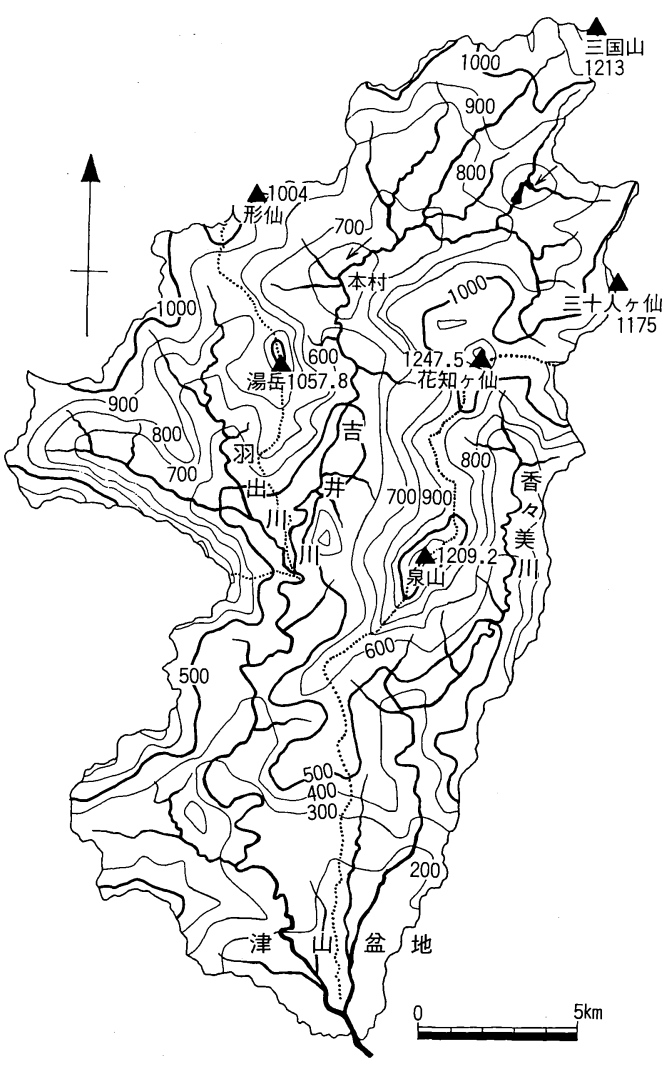

第 1 図 吉井川上流域の接峯面

5 万分の 1 地形図をもとに，幅 $1 \mathrm{~km}$ の谷を埋めて作成。 点線は流域区分を示す。

のため，濁水紛争の発生が鉄穴場の分布にいか なる影響を与えたのかについて検討するにあた り，吉井川上流域はふさわしい地域といえる。

鉄穴跡地の存在は，鉄穴場がかつてそこに立 地していたことを示す。そして面積の広い鉄穴 跡地は，鉄穴流しの活発な稼行，換言すれば鉄

8） (1)赤木祥彦「中国山地における砂鉄産地一地形的立地と地形変形一」, 史学研究75，1960，47一65頁。(2)赤木祥彦・貞 方昇「高梁川流域の鉄穴流しによる地形改変と水田開発」，人文地理40，1988，197-220頁。

9）貞方 昇「島根県横田町周辺の鉄穴流し跡の地形」（石田寛教授退官記念事業会編『地域一その文化と自然一』福武書 店，1982）368一-378頁。(2)貞方 昇「斐伊川流域における鉄穴流しによる地形改変」，地理学評論55，1982，690一706頁。 (3)貞方 昇「山陰地方における鉄穴流しによる地形改変と平野形成」，第四紀研究24，1985，167-176頁。(4)貞方昇・赤 木祥彦「鳥取県日野川流域の鉄穴流しによる改変」，たたら研究27，1985，1-13頁。

10）藤井駿・加原耕作『備中湛井十二箇郷用水史】, 湛井十二箇郷組合, 1976。

11）宗森英之「美作国における鉄穴稼と濁流問題」（水野恭一郎先生頌寿記念論文集『日本宗教社会史論叢』，国書刊行会， 1982）581一602頁。

12）加原耕作「備中浜村一件一高梁川筋における鉄穴稼と濁流問題一」（藤井駿先生喜寿記念会編『岡山の歴史と文化』，福 武書店，1983）384-404頁。

13）安藤精一「近世中国地方の公害」（安藤精一『近世公害史の研究』，吉川弘文館，1991）189-254頁。 
穴場の集中を示しているとみなせよう。空中写 真の判読と現地調査によって明らかにされた鉄 穴跡地の分布は, 研究対象地域全体における鉄 穴場の分布にほほ対応している。そこで本研究 では，まず空中写真の判読と現地調査によって， 鉄穴跡地の分布とそれの分布する地域の地形・ 地質条件を把握する。つぎに, 史・資料から, 鉄穴流しの稼行状況やその存在意義, 濁水紛争 の実態などを明らかにし，それらとの関わりよ り, 鉄穴場の分布を規定した要因について検討 する。

\section{II 吉井川上流域の地理的性格と鑪製鉄}

( 1 )吉井川上流域の地理的性格 吉井川は中 国脊梁山地の一角をなす作北山地の登国山 (1213m) 付近に源を発し, 津山盆地を経て瀨戸 内海へ注ぐ全長 $137.5 \mathrm{~km}$ の河川である。鉄穴 流しが活発に行われる地域は, 地質的には花崗 岩類のなかでも花崗閃緑岩ないし閃緑岩である ことから, 津山盆地以北の吉井川流域のなかで, 鉄穴流しの対象となりうる花崗岩類が地質図上 で分布する地域を本稿では吉井川上流域とする。 当地域には, 主として北部に黒雲母花崗岩が, 南部と三十人ケ仙西麓には花崗閃緑岩などの花 崗岩類が分布している(第 2 図)。現在の行政区 画からみると吉井川上流域は, 岡山県笘备郡上 齊原村と箱地区以北の奥津町, 鏡野町越畑地区 の 3 町村にまたがっている。

中国山地にはお扮むね 3 段にわたる小起伏面 が発達しており，この点において吉井川流域も 例外ではない(第 1 図)。道後山面や吾妻山面と よばれる標高1000～1200 m の高位小起伏面は, 湯岳 $(1057.8 \mathrm{~m})$, 花知ヶ仙 $(1247.5 \mathrm{~m})$, 三十人

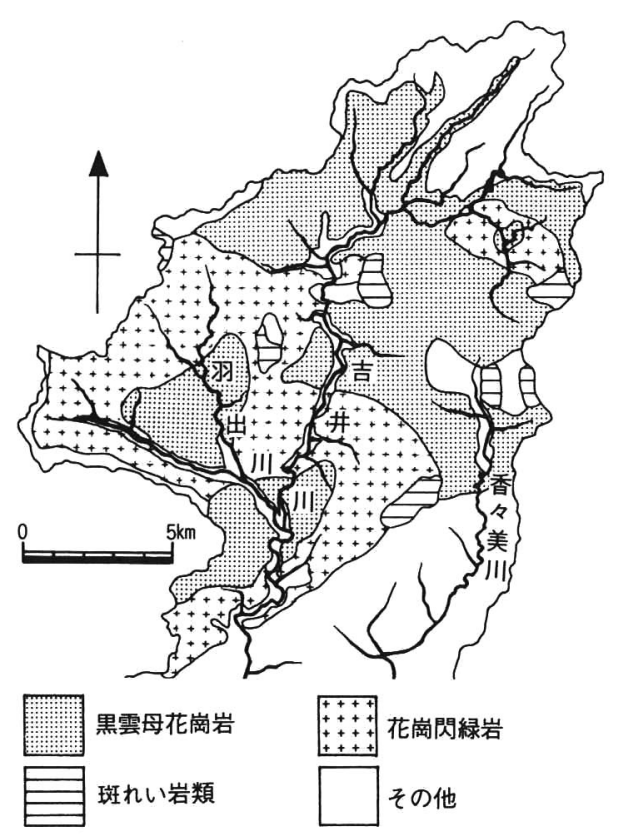

第 2 図 吉井川上流域における花崗岩類の分布 資料 : 脚注33）の付図

ケ仙 $(1175 \mathrm{~m})$ ， 泉山が (1209.2 m) などの山頂 付近に発達している。そして, 吉備高原面とよ ばれる標高500〜 700 m の中位小起伏面は, 現上 齊原村泩村の位置する山間盆地周辺や泉山山麓, 湯岳山簏などに広くみられる。下位小起伏面は, 研究対象地域より下流の津山盆地以南に扔いて 確認できる。また，これら 3 段の小起伏面とは 別に, 当地域では標高 $800 \mathrm{~m}$ 前後の地域におい て, 比較的広い面積を有する小起伏面もみとめ られる。なお, 高位小起伏面と標高 $800 \mathrm{~m}$ 前後 の小起伏面には, 凹地状の地形面が広く発達し ている。

（2）鑪製鉄・鉄穴流しの稼行享保 10 (1725) 年の編とされる地誌書『作州記』には, 元禄10（1697）年の鑪の所在地として上齊原村

14）なお，空中写真の判読と現地調査にもとづいて，鉄穴流しによる砂鉄生産量を推定するためには，鉄穴跡地の面積のみ ならず鉄穴場の地形的位置によって異なる採掘土厚をも考慮する必要がある。吉井川上流域に近似した地形条件をもつと 考えられる高梁川流域において, 鉄穴流しによる採掘土厚は, 山頂緩斜面では $8 \sim 10 \mathrm{~m}$, 山腹緩斜面では $5 \sim 10 \mathrm{~m}$, 山麓 緩斜面では $6 \sim 8 \mathrm{~m}$ ，山頂・尾根部や山腹急斜面では $2 \sim 4 \mathrm{~m}$ と見積もられている。前掲8) (2)208頁。

15）たとえば，前揭9) (3)175頁。

16）この地形面は, 人形峠面と呼ばれている。小畑 浩『中国地方の地形」, 古今書院, 1992, 30-31頁, 182-184頁。

17）津田重倫『作州記」, 1725,（吉備群書集成刊行会編『吉備群書集成第 1 輯 地誌部上d, 同会, 1921) 47頁。 
と翡出村 (以下, すべての村名は藩政村を示す) が 記録されている。これ以降, 各種の史・資料に よって上齊原村の人形仙・木路・池河 · 中津河 ・豊ヶ谷・遠藤・杉小屋や, 養野・参䓔野・奥 津・下齊原・羽出・越畑村など調查対象地域の 広い範囲にわたる鑪製鉄の立地が確認できる (第 3 図)。

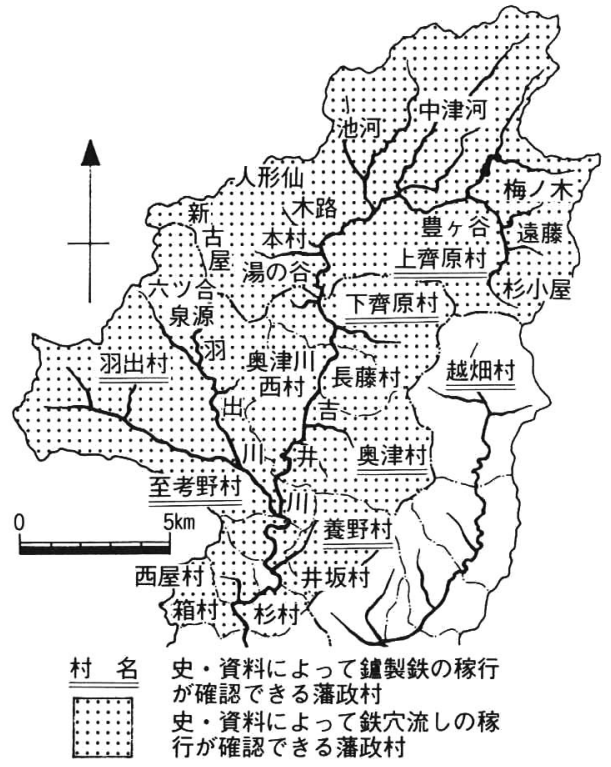

第 3 図 吉井川上流域における鑪製鉄と鉄穴流 しの稼行状況

資料：脚注11)，17），18）(1)，(2)，(3)，22）など

一方，史・資料によれば，鉄穴流しの稼行が 確認される鉄穴稼ぎ村は, 当地域ではもっとも 早いもので18世紀初頭以降であり, その後, 上 齊原, 下齊原, 奥津川西, 長藤, 奥津, 羽出, 養野，至考野，西屋，井坂，箱，杉の12か村に およんた（第 3 図）。
鉄穴場の数について確認できる史・資料は非 常に少ないが，たとえば元文 4 (1739）年から 寛保 2（1742）年にかけて，下齊原村みつこ原 鑪に 3 か所，上齊原村といが谷鑪に 4 か所の鉄 穴場が設置されている。文化元 (1804) 年には 7 か所の鉄穴場が確認できるものの, 近世末期 には，後述する濁水紛争のために，その数はわ ずか 2 か所に限定されていた。しかし，明治期 における鉄穴流しの稼行制限はやや緩和された ようであり，同 5（1874）年には，上齊原，箱， 長藤の 3 か村で計 5 か所の鉄穴場が確認できる。

当地域の鉄穴場は，史・資料に記載されてい るものだけであろうか。次章では地形学的に鉄 穴場の分布について検討する。

\section{III 地形・地質条件よりみた鉄穴流し稼行地 点の分布}

(1)鉄穴跡地の地形的特色 空中写真の判読 と現地調查によって鉄穴跡地の具体的な分布を 把握するのに先立って，三十人ケ仙の西麓に位 置する上齊原村杉小屋地区と，同村の中心集落 が立地する本村地区を例にして，鉄穴跡地の地 形的特色を明らかにする。

鉄穴跡地は，地形改変を受けた当時の状態を ほぼそのまま残す一次改変地と, 耕地や宅地な どとして利用するためにふたたび改変された二 次改変地とに大別される。高位小起伏面とその 山麓緩斜面の発達する杉小屋地区の空中写真 (第 4 図)を判読すると，起伏にとぼしい自然斜 面（図中 A 地点）のなかに，微起伏に富む小凹 地（同B地点）を見いだすことができる。この

18）たとえば，(1)定本正芳「美作西北部の鉄山業と地域社会の変貌」，たたら研究 $3 \cdot 4 ， 1959 \cdot 1960,1-8$ 頁・10一20 頁。(2)宗森英之「岡山県の製鉄地分布図」，たたら研究10，1963，14一-18頁。(3)岡山県『岡山県史 第 7 巻 近世 II』，岡 山県, 1985, 374一-418頁。

19）前掲11）583頁。

20）寛保二年「西々條郡養野村 奥津村 下齊原村 上齊原村 鉄山聞合七上帳」，津山市矢吹家文書，（山中一揆顕彰会編 『第一回山中一揆調査史料』, 同会, 1956） $7-9$ 頁。

21）前掲11）586頁。

22）岡山大学教育学部社会科教室地域研究会編「中国山地の村一岡山県苫田郡上齊原村一」, 地域研究19, 1976, 104頁。

23）北条県『北条県史』，1947，(国立公文館所蔵，岡山県史編纂室撮影本，宗森英之氏提供）。

24）たとえば，前掲8）(2)202頁。 

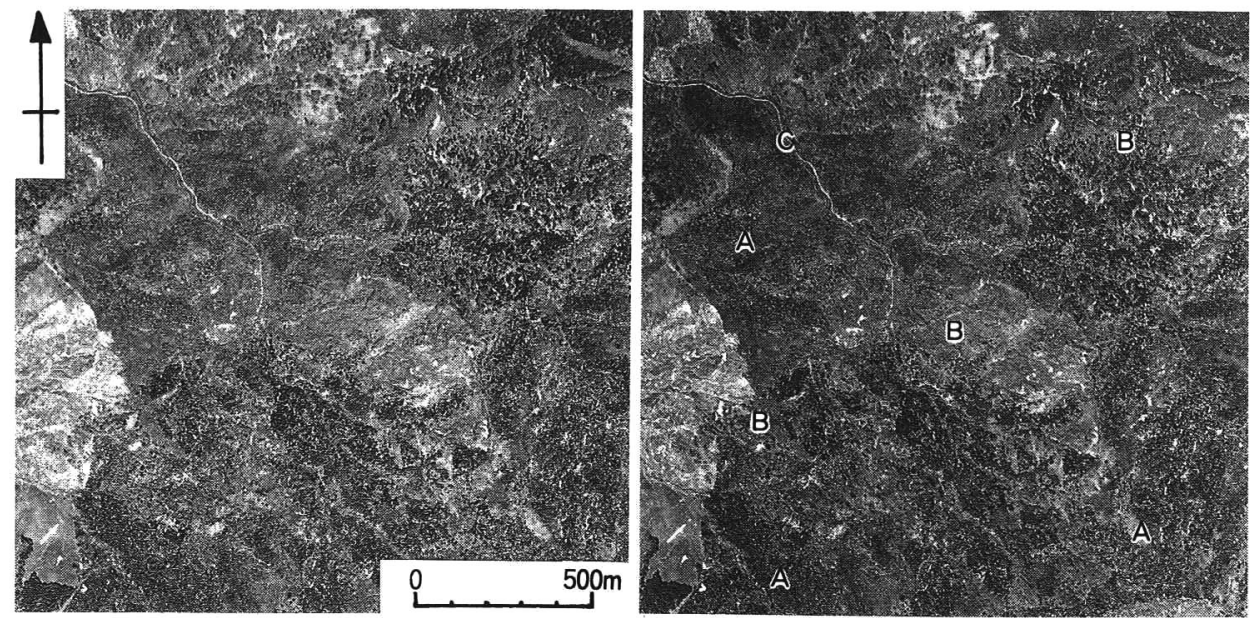

第 4 図 上齊原村杉小屋地区における鉄穴跡地の地形

三十人ヶ仙西麓には，高位小起伏面に属する凹地状の地形面が広く発達している。実体視を行うと，起伏にとほし い平滑な自然斜面（A）のなかに, 微起伏に富む小凹地が確認できる（B）。この部分が鉄穴跡地である。なお， 現地調査によると，付近の谷底では，鉄穴流しの廃砂によるものと思われる埋積の進行が確認できる（C）。 写真: 林野庁撮影・ 2 万分の 1 空中写真,「チヅ 山一 578 (オクッ) $\quad$ C 4-15・16 1970年」

小凹地の周囲に分布する植生が見られない馬蹄 形の急崖は，最終の切羽となったところと考え られる。多数確認できる鋭い稜角をもつ尾根は, 「ホネ」と呼ばれ，原地形の支尾根に対して直 交方向に両側から掘り崩されたものである。ま た，鉄穴流しによって掘り残されたと考えられ る鉄穴残丘も多く存在している。これらの地形 が複雑に入りくんでいるところは，鉄穴跡地の 一次改変地として認定される (第 5 図)。

一方，標高 $500 \mathrm{~m}$ 前後の山間盆地に位置する 本村地区には，中位小起伏面に属する山簏緩斜 面がよく発達している。この地区においても， 杉小屋地区で確認されたものと同様の一次改変 地が広く存在している(第6図)。しかし，第 6 図に記した $\mathrm{A}$ 地点の水田は, 周辺の水田と比べ 土地割が著しく異なり, 微起伏に富んでいるこ とから，鉄穴跡地に造成されたものと考えられ る。B地点の耕地もまた, 鉄穴残丘 (図中 C 地 点）の存在を手がかりにすると，鉄穴跡地に造 成されたものとしてみなすことができる。この

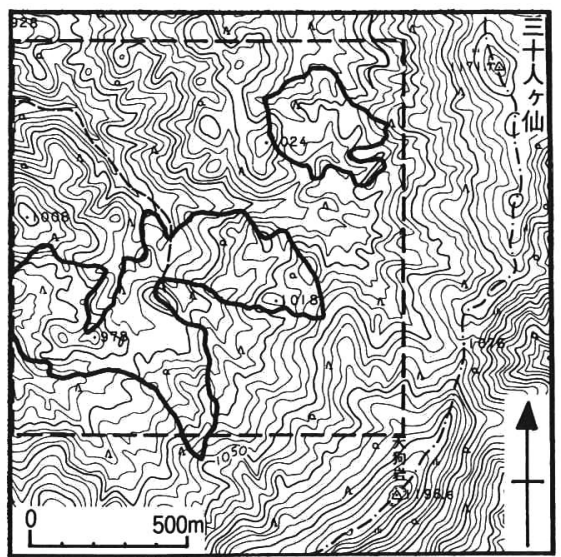

第 5 図 上齊原村杉小屋地区の地形

破線によって囲まれた部分は，第4 図の範囲を示す。実線に よって囲まれた部分が铁穴跡地である。

資料：国土地理院発行・ 2 万 5 千分の 1 地形図「加瀨木」

ように，鉄穴残丘および支谷の水系とは不調和 に整地された耕地形態より，耕地として利用す るために整地されたところは，鉄穴跡地の二次 改変地として認定できる。これら二次改変地の 原地形は， A 地点北部の山地側に切羽跡と考え られる急崖や， C 地点に鉄穴残丘が存在するこ

25）たとえば，前掲8) (2)202-204頁。

26）たとえば，前揭8) (2)204一206頁。 


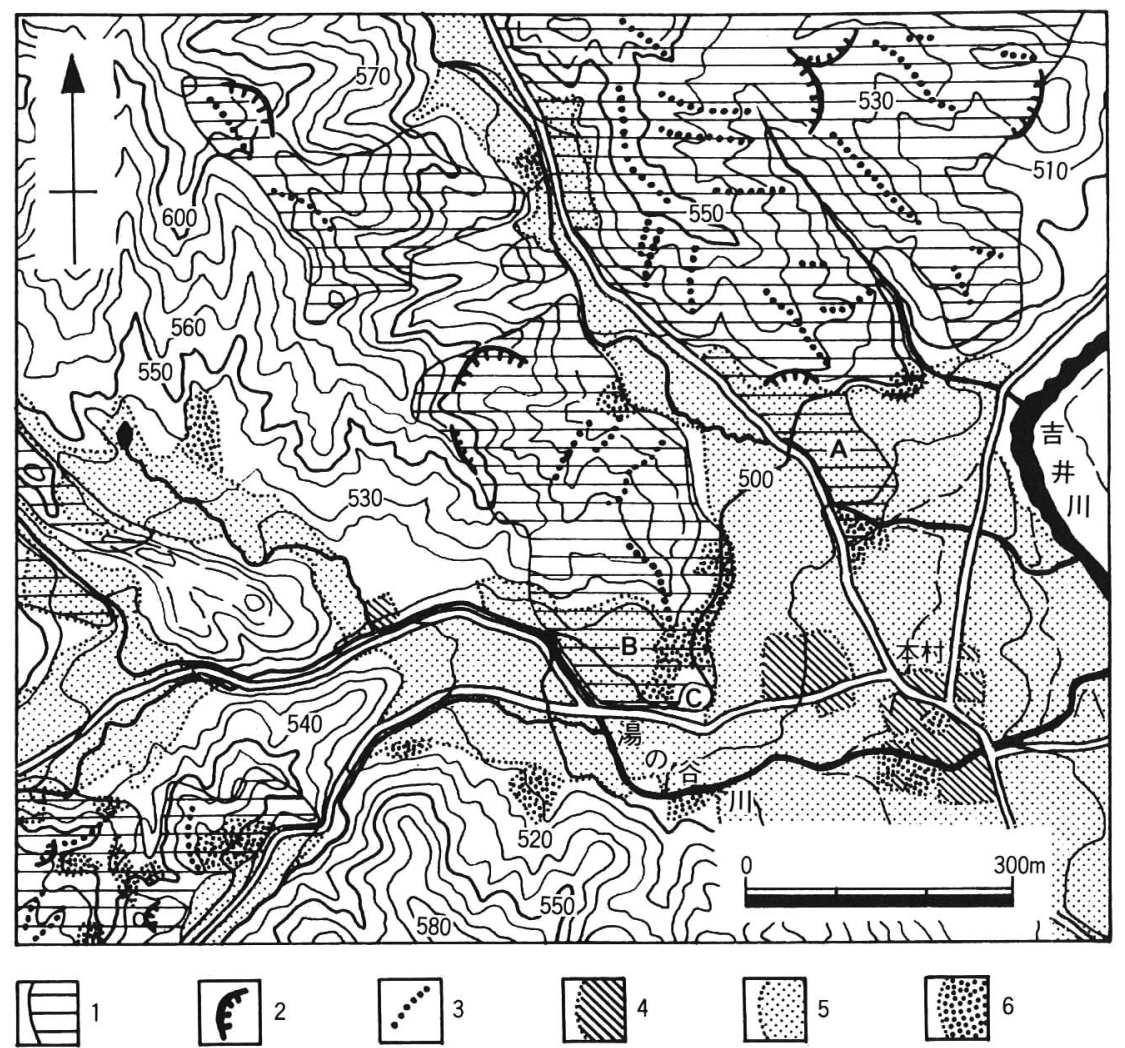

第 6 図上齊原村本村地区の鉄穴跡地と土地利用

1. 鉄穴流しによって掘り崩された土地（鉄穴跡地）。2．植生のみられない急崖(切羽跡)。3. 鋭 い稜角をもつ尾根（ホネ）。4 . 宅地。5.水田。6. 畑。

本図の等高線は 3,000 分の 1 「森林基本図」による。地籍図および土地台帳によって, 本村地区の鉄穴 跡地にもっとも多くの耕地が確認できたのは, 明治20（1887）年であった。そのため土地利用につい ては，明治20年の状況を復原しておいた。

とから，盆地内部に突き出した山簏緩斜面の支 尾根であると思われる。

ここで把握できた鉄穴跡地の地形的特色を手 がかりとして, 次節では, 吉井川上流域全体に 扮ける鉄穴跡地の地理的分布を明らかにする。

(2)地形・地質条件よりみた鉄穴流し稼行地 点の分布 第 7 図は, 空中写真の判読と現地調 査によって認定された，対象地域における鉄穴 跡地の分布を, 2 万 5 千分の 1 地形図を基図と して示したものである。対象地域における鉄穴
跡地の総面積は571.5 ha であり，このうちの 93.6\%（534.7 ha）が吉井川の本流域に分布す る(第 1 表)。地形的には, 吉井川上流域で鉄穴 流しにもっとも適しているのは，高位小起伏面 に属する三十人ケ仙西麓と, 人形仙南東篦に位 置する標高 $800 \mathrm{~m}$ 前後の小起伏面，さらには泉 山西麓や湯岳北麓, 上齊原村本村周辺など, 中 位小起伏面に属する山麓緩斜面などと考えられ る。全体として，鉄穴流しが活発に行われる地 域は小起伏面であり，かつ砂鉄採取用水路が設

27）判読にあたっては， 2 万分の 1 空中写真（1970年，林野庁撮影）と，1万拈よび 1 万 5 千分の 1 空中写真（1976年，国 土地理院撮影）を併用した。なお鉄穴跡地の認定の際，障害となりやすい植林の有無，あるいは森林の成育状況の差から， 2 万分の 1 空中写真も有用であった。 


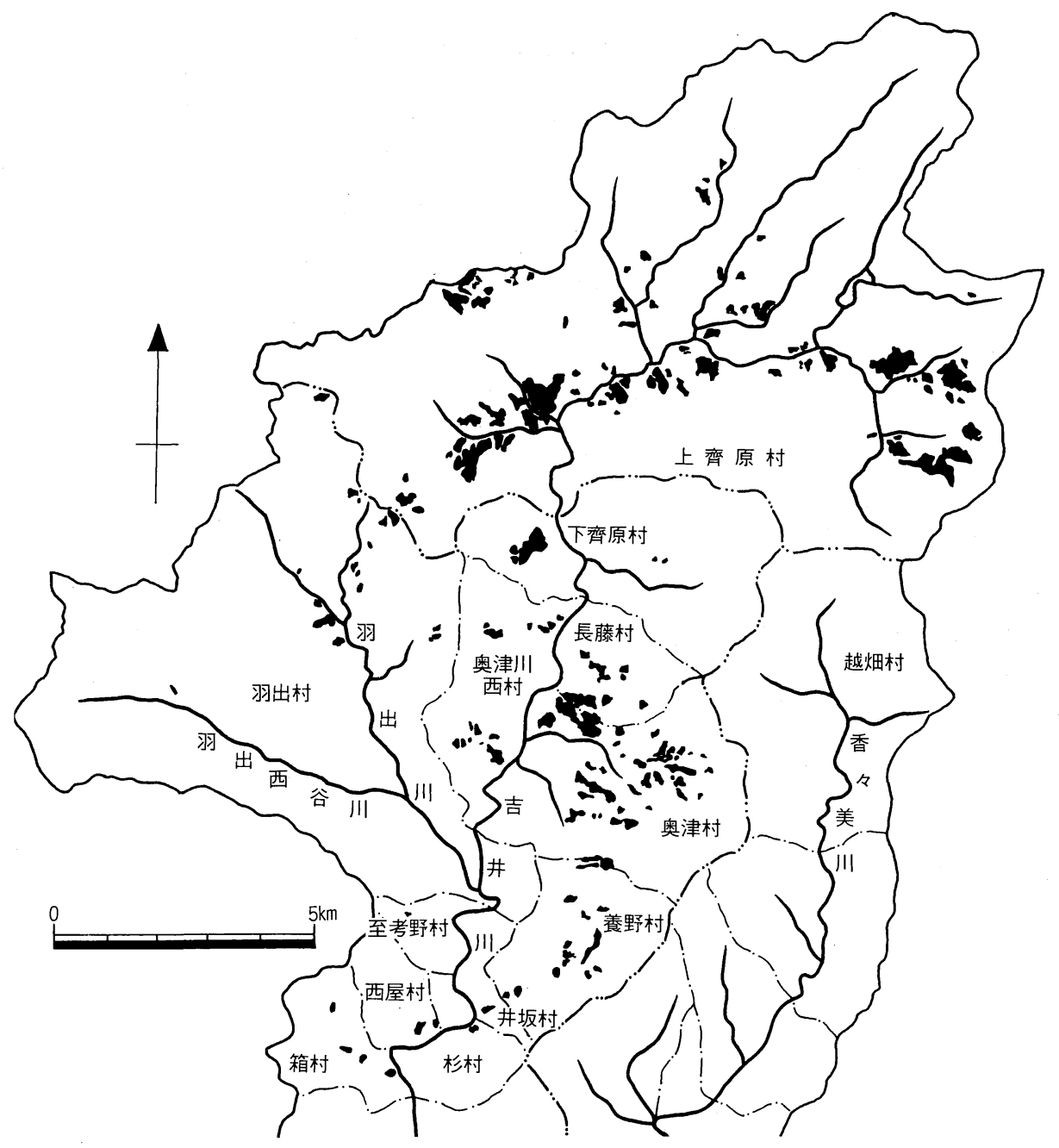

第 7 図 吉井川上流域における鉄穴跡地の分布

1 万分の 1,1 万 5 千分の 1,2 万分の 1 空中写真で判読した鉄穴跡地を， 2 万 5 千分の 1 地形図に記入し たのち，縮小したものである。

置しやすいという地形条件をそなえている。こ の結果は，従来の成果と調和的である。吉井川 の本流域において，鉄穴跡地のとくに集中する ところは，三十人ケ仙西麓に位置する上齊原村 の遠藤・杉小屋・梅ノ木, 人形仙付近, 湯岳北 麓の湯の谷・本村周辺, 泉山西麓の長藤・奥津 ・養野村などである。つぎに，村レベルでみる と，鉄穴跡地の分布域（第 7 図）と，史・資料 によって鉄穴流しの稼行が確認された 12 の鉄穴
稼ぎ村（第 3 図）とは，よく一致している。鉄 穴跡地を藩政村ごとにみると, 跡地面積のもっ とも広い村は上齊原村 (361.7 ha，全体の63.3\%) であり，奥津村 (83.8 ha, 全体の $14.7 \%$ ) がそれ に次いでいる。そして村面積に占める跡地面積 の割合がもっとも高いのは, 奥津村 (6.0\%) で ある。

つぎに地質についてみると，鉄穴跡地がとり わけ集中する地域の地質は, 前述したように花

28）たとえば，前掲9）(3175頁。 
第 1 表 吉井川上流域における鉄穴跡地の面積

\begin{tabular}{|c|c|c|c|c|}
\hline 流域名 & 藩政村 & 村面積 ${ }^{3)} \mathrm{A}$ & $\begin{array}{l}\text { 鉄穴跡地 } \\
\text { 面積 }{ }^{4)} B\end{array}$ & $\frac{\mathrm{B} \times 100}{\mathrm{~A}}$ \\
\hline \multirow{11}{*}{$\begin{array}{l}\text { 吉 } \\
\text { 茾 } \\
\text { 本 } \\
\text { 流 } \\
\text { 域 }\end{array}$} & 上齊原村 ${ }^{1}$ & $8,344.0$ & 353.9 & $4.2 \%$ \\
\hline & 下齊原 村 & $1,438.0$ & 20.1 & 1.4 \\
\hline & 長 藤 村 & 431.5 & 23.1 & 5.4 \\
\hline & 奥 津 村 & $1,391.3$ & 83.8 & 6.0 \\
\hline & 奥津川西村 & 800.3 & 19.2 & 2.4 \\
\hline & 養 野 村 & 725.3 & 24.6 & 3.4 \\
\hline & 井 坂 村 & 192.8 & 1.6 & 0.8 \\
\hline & 至考野村 & 207.3 & 0.5 & 0.2 \\
\hline & 西 屋 村 & 257.5 & 2.4 & 0.9 \\
\hline & 箱 & 445.3 & 4.9 & 1.1 \\
\hline & 杉 & 284.0 & 0.6 & 0.2 \\
\hline & 上齊原村 ${ }^{2}$ ) & 523.0 & 7.8 & 0.1 \\
\hline \multirow[t]{2}{*}{ 流 域 } & 羽 出 村 & $5,041.3$ & 29.0 & 0.6 \\
\hline & 合 計 & $20,149.9$ & 571.5 & 2.8 \\
\hline
\end{tabular}

単位: ha。 ${ }^{1}$ 羽出川流域をのぞく。 ${ }^{2)}$ 上齊原村のなかで 羽出川流域に該当する地区 (新古屋地区)。 ${ }^{3}$ 地形図上 で方眼法によって計測。 ${ }^{4)}$ 空中写真の判読後, 地形図上 に記載したものを方眼法によって計測。

崗岩類のなかでも砂鉄含有量が幾分多い花崗閃 緑岩や閃緑岩であるとされている。

ところで，香々美川流域のなかで唯一花崗岩 類が分布し，中位小起伏面に属すると考えられ る山麓緩斜面の見られる越畑村において，鉄穴 跡地は確認できなかった。現在のところ，史・ 資料や小字地名の検討においても，香々美川流 域における鉄穴流しの稼行を示唆するようなも のは，まったく見つからない。また安永元 （1772）年，越畑村から代官所へ提出された鑪 製鉄の稼行願いには，「勿論村中鉄砂取り所も 御座候一共, 場所柄悪敷行届キ不申間, 西々条 郡上才原村之内杉小屋与申所二車乙重次郎と申 者鉄砂取り申候所，壱ケ所御許容被遊候八、銀 主御取候間右奉願上候」とある。これによると， 越畑村に「鉄砂取り所」は存在するものの（下 線部(1)，「場所柄」が悪い（下線部(2)）ので，上
齊原村杉小屋鉄穴場（下線部(3)）から砂鉄を輸 送することによって鑪製鉄を行いたいと，引用 した箇所に続いて記されている。この地域に分 布する黒雲母花崗岩は，磁鉄鉱分にとぼしいと いう性質をもつことからすると，「場所柄悪敷」 とは地質条件が鉄穴流しに適していないことを 示すと考えられる。香々美川流域では，(1)地形 的には鉄穴跡地を認めることができない，(2)鉄 穴流しの稼行に関する史・資料は未発見である， (3)鉄穴流しに関連すると思われる地名が現存し ない，(4)鑪製鉄の原料を流域外から入手してい る，(5)地質条件が鉄穴流しには必ずしも適さな い。以上の 5 つの点から，この地域では本格的 な鉄穴流しが行われなかったと考えられる。

羽出川流域の鉄穴跡地は，対象地域のわずか 6.4\%（36.8 ha）を占めるにすぎない。この原 因も地形・地質条件から説明できる。羽出川流 域には，中位小起伏面に属すると考えられる山 麓緩斜面がよく発達している。しかし，もっと も広く分布する地質は，先述した越畑村の黒雲 母花崗岩と近似した性質をもつことから，鉄穴 流しには適さなかったと考えられる。また，羽 出西谷川の右岸側には花崗閃緑岩が分布し地質 条件は満たすものの，勾配が急であることから， 地形条件が鉄穴流しに適さない。羽出川流域の うち，鉄穴流しに適した地形・地質条件をそな えるのは, 羽出村の泉源・六ツ合地区, 上齊原 村新古屋地区などわずかの地域に限られる。

ところで，吉井川上流域の花崗岩地域の地質 は，南部に花崗閃緑岩が，北部に砂鉄含有量の やや少ない黒雲母花崗岩が広く分布している。 このような地質条件にもかかわらず，吉井川上 流域の鉄穴跡地は黒雲母花崗岩の広がる北部に

29）たとえば，前揭9) (3)175頁。

30）越畑村の字名一覧には，鉄穴流しに関連すると思われる小字名は皆無である。鏡野町史編集委員会・同教育委員会編 『鏡野町史 民俗編』, 同町発行, 1993，518-521頁。

31）安永元年「乍恐奉願上候御事」(越畑村瀬畑家文書), (宗森英之「美作国越畑村の鉄山業について」，たたら研究 12 , 1965，47頁)。なおこの文献では，越畑村の鉄穴流しについてはまったく検討されていない。

32）今村外治ほか編『日本地方地質誌 中国地方（新版)」，朝倉書店，1984，89頁。

33）笹田政克ほか「東中国，三朝・奥津・湯原の白亜期後期～古第三紀火成岩類」，地質学論集17，1979，25頁。 
集中している。

この原因として，地形条件の違いがあげられ よう。すなわち，黒雲母花崗岩の広く分布する 高位小起伏面や標高 $800 \mathrm{~m}$ 前後の小起伏面には, 凹地状の地形面が広く発達していることから， 鉄穴流しに利用する水の確保が容易であり，か つ, 花崗岩類の風化層が厚く存在していたと考 えられる。その結果，この地域に分布する鉄穴 跡地は，1つあたりの面積がきわめて広くなっ ている(第 7 図)。他方，花崗閃緑岩の広がる中 位小起伏面上においては，支谷が発達している ため，鉄穴流しの対象となる風化層は，尾根の 頂部にのみ残存している。その結果，ここに位 置する鉄穴跡地 1 つあたりの面積は, 狭長な形 状をとるものが多いため，おおむねせまい。し たがって，高位小起伏面上で確認されるような， 広い面積にわたる規模の大きな鉄穴流しは，中 位小起伏面上では行なえなかったと考えられる。 このような地形条件の相違によって，鉄穴跡地 は北部の，砂鉄含有量のやや少ない黒雲母花崗 岩地域に集中することになった可能性が高い。

しかし, 鉄穴跡地が北部の, 地質的にやや条 件が悪い黑雲母花崗岩地域に集中した点につい ては，自然条件のみでなく，人文条件の面から も検討することが必要であると思われる。

\section{IV 濁水紛争よりみた鉄穴流し稼行地点の分 布}

（1）鉄穴流しの存在意義 文政 7（1824）年
の史料には，「上齊原村并二下齊原・奥津村二 而者慶長八歳御当国検地入之節鉄山場御取調別 高二御改被仰付全作毛八取不申場所柄二御座候 得共右稼御見込之御検地入二被仰付」とある。 ここでは，慶長 8 (1603) 年に,「鉄山場」を 調査したうえで村高が改められた（下線部(1)）。 その際，「右稼」すなわち鉄穴流しや鑪製鉄に よる収入を見込んだうえで検地がなされたこと （下線部(2)）が主張されている。鉄穴流しや鑪製 鉄による農民の収益が近世の貢租体系のなかに 組み込まれている事例は，管見の限りでは，備 後や安芸, 出雲国において確認されている。

さらに出雲国では,「往昔ら有来之鉄山相止 メ候而八仁多飯石之山郡諸働無御座御成稼上納 不相成難儀仕候二付年々御願申上候得共御許容 なし無拠奥山迄山畑伐ひらき難渋之渡世を送り 申候」とあるように，鉄穴流しの差し止め（下 線部(1)）によって，「御成稼」分を上納できず に農民が困窮している(下線部(2)。同様に，伯 老国においても，「奥日野郡八極山中之儀二付 別二冬春稼方無御座場所柄二御座候処鉄穴口沢 山二御座候 (中略) 全此融通を以御年貢銀納二 て相定候儀二御座候」とある の稼ぎ分をもとに年貢を納めている（下線部） ことがわかる。これらの史料によっても，鉄穴 流しが差し止められれば，それに従事していた 農民が，生活や年貢の上納に困窮したことが明 らかである。

さらに鉄穴流しの差し止めは，鑪製鉄の稼行

34）前掲9) (1)378頁。

35）南部の花崗閃緑岩地域では，尾根の頂部を中心に鉄穴流しが行われているため，掘り崩し土砂量と砂鉄生産量は，一般 に少ないものと思われる。一方, 黒雲母花崗岩の広く分布する北部の高位小起伏面や, 標高 $800 \mathrm{~m}$ 前後の小起伏面では, 厚く土砂を掘り崩すことが可能であった。これらの点を考慮すると，鉄穴流しによる砂鉄生産量は，鉄穴跡地の面積にも とづいて考察する以上に，北部に扔いて多かったと考えられる。前掲14)。

36）文政 7 年「覚」(上齊原村田渕家文書), (上齊原村教育委員会村誌編纂室所蔵)。以下, 田㴊家文書については, 同教育 委員会が所蔵しているものを利用させていただいた。

37）つぎの史料によると，慶長の鉄山検地によって決定された上齊原村の「鉄山高」は 62 石 3 升 2 合である。文政 8 年「鉄 山高取調書上帳」(上齊原村田㴊家文書)。

38）松尾媰太郎「中国地方の鉄山行政と地方経済(上)」, 歴史地理 $58 ， 1931 ， 340$ 頁。土井作治「広島藩営鉄山の成立とその 構造」（渡辺則文編『産業の発達と地域社会』, 渓水社, 1982）192-202頁。

39）正徳～嘉永年間「系原家鉄山旧記写」(島根県横田町系原家文書), (島根県『新修島根県史 史料篇 2 近世上』, 1965）584一612頁。

40） 文久 2 年「奉願口上之覚」(鳥取県日野町近藤家文書)，(鳥取県『鳥取県史 第 8 巻 近世資料』，1977）619一621頁。 
にも支障をきたすことになる。これまでも指摘 されているように，鑪製鉄はその稼行地域の農 民に対し，多大な経済的効果をもたらした。こ の点について，上齊原村を事例として検討する と, 天保 9 (1838) 年の史料には, 「極山中故 深霜所々御座候往古森美作守様松平越後守様御 領分之節数十年来鉄山稼被仰付御料所二相成候 而も鉄小割鍛冶稼被仰付御運上差上相稼居申候 二付当村不限奥五ケ村者米穀等右稼場へ売払運 送之費無御座候其上村内之もの農業之間右荷物 送り等之働仕助情二相成御年貢御納所無滞相勤 居申候」とある。すなわち，鑪製鉄に関連する 小割鍛冶へ米穀を納入することで年貢輸送に必 要な費用が軽減できること（下線部(1)）や，鑪 製鉄に関連する荷物輸送への従事が可能である こと（下線部(2)）などを読み取ることができる。 このほかにも，鑪製鉄に直接従事する，あるい は木炭の製造に加わることなど，さまざまな形 で農民へ収益がもたらされたのである。

また，文化 9 （1812）年, 吉井川上流域の鉄 穴稼ぎ村は，幕府領から津山藩領あるいは津山 藩預り地となって幕末をむかえた。近世末期の 津山藩は，天保 5 （1834）年には藩営鉄山を設 置しているように，鑪製鉄の経営に積極的に乗 り出している。その結果, 近世末期は, 吉井川 上流における鑪製鉄の最盛期とされている。し かし藩営鉄山の盛行は, 領内のみならず下流の 岡山藩に対し，鉄穴流しにともなう濁水の被害
を与えかねない。したがって，岡山藩との濁水 紛争を未然に防ぎつつ，鉄穴流しの稼行を継続 することは，積極的な産鉄政策を進めようとす る近世末期の津山藩にとって，きわめて重要な 課題であったと思われる。

これまでみてきたように，農民のみならず津 山藩にとっても，鉄穴流しの存在意義はきわめ て重要であった。それだけに，鉄穴流しの稼行 制限は，農民や津山藩に深刻な影響を与えるこ とになった。その一方で，濁水紛争は，農民の 生活や藩政にとどまらず，鉄穴場の分布にも大 きな影響を与えたのである。

\section{(2)濁水紛争よりみた鉄穴流し稼行地点の分}

布 濁水紛争に関する研究は，前述したように 文献史学の立場から蓄積されてきた。そのなか で宗森英之先文安藤精一の業績は, 吉井川上流域 を含む美作国の濁水紛争について検討している。 しかし，両者とも濁水紛争が鉄穴場の分布に与 えた影響に関する分析は行っていない。そこで， 本節ではこれらの研究成果とともに，ほかの史 ・資料をも援用しつつ, 濁水紛争の状況を把握 したうえで，鉄穴場の分布について考察する。

吉井川上流域に㧍ける濁水紛争の初見は，宝 永 4 (1707) 年のものである。この紛争の発端 は，上齊原村と羽出村から生じた濁水が舟運に 被害を与えたことにあり，下流の 3 か村は上齊 原村と羽出村に対し，鉄穴流しの差し止めを求 めた。しかし，農民の生活に支障をきたすこと

41）向井義郎「中国山脈の鉄」，地方史研究協議会編『日本産業史大系 7 中国四国地方篇』，東京大学出版，1960）164一 203頁。

42）天保 9 年「西々條郡上齊原村明細書上帳」(上齊原村田㴊家文書)。

43）上齊原村で生産された年貢米は，「当御城下江付出申駄賃入用之義米壱石二付拾壱多位相懸下地困窮之百姓至極迷惑仕 候」とあるように，上齊原村の百姓にとって大きな経済的負担となりつつ，津山城下へ運搬されていた。前揭42）。鑪へ 直接納入する年貢米は「為替米」とよばれ，その意義についてはつぎの文献にくわしい。前揭41）187頁。

44）農民が荷物輸送や鑪製鉄に直接従事する状況は，上齊原村遠藤の栄金山鑪において筆者も確認している。拙稿「近代以 降における夕夕ラ起源集落の再編成一岡山県苫田郡上齊原村遠藤の場合一」, 立命館地理学 $6,1994,29-45$ 頁。

45）平凡社地方資料センター編『日本歴史地名大系 第34巻 岡山県の地名』, 平凡社, 1988, 148一153頁。

46）前揭18) (3)400頁。

47）苫田郡教育会編『苫田郡誌』，同会，1927，114頁。

48）前揭11）581一602頁。

49）前掲13）189-254頁。

50）前掲11）583頁。 
から，すべての鉄穴流しの差し止めには至らな かった。その後も鉄穴流しの稼行と濁水紛争の 発生がさまざまな史料から確認される。享保 2 （1717）年においても，鉄穴流しは差し止め中 であり，同13・16年には，鉄穴流しの差し止め が求められている（第 2 表)。さらに，延享 4 (1747) 年, 備前国岡山藩の公儀提訴によって, 鳥取藩の預り所となっていた吉井川上流域の鉄
穴流しは，宝暦 2（1752）年までに差し止めら れることになった。

ついで文化元 (1804) 年には, 下流の28か村 が, 上齊原, 奥津, 長藤, 養野, 箱の 5 か村で 行われた鉄穴流しに対し，その差し止めを求め ている。しかし，上齊原村のみがこれに同意し なかったため, 同 3 年にふたたび濁水紛争が生 じた。上齊原村が鉄穴流しの差し止め要求を受

第 2 表 近世の吉井川上流域における鉄穴流しと濁水紛争の状況

\begin{tabular}{|c|c|c|c|}
\hline 年 & 鉄穴流しの稼行と濁水紛争の状況 & 原 & 引用文献 \\
\hline 宝永 4 (1707)年 & $\begin{array}{l}\text { 羽出・上齊原村の鉄究流しに対し, 差し止めが求められ } \\
\text { たものの, 百姓が困窮するため, 鉄穴流しの継続がみと } \\
\text { められた。 }\end{array}$ & 宝永 4 年「差上申一札之事」 & 脚注20） \\
\hline 享保13(1728)年 & $\begin{array}{l}\text { 養野·奥津 · 下齊原・上齊原村の鉄穴の差し止めが, 公 } \\
\text { 儀に求められた。 }\end{array}$ & 延享 4 年「作州鉄山之一件」 & 脚注11） \\
\hline 享保16(1731)年 & 濁水の発生によって川渡りに支障がでている。 & 享保16年「御断申上ル御事」. & 脚注20） \\
\hline 寛保 2 (1742)年 & $\begin{array}{l}\text { 鉄穴場 } 7 \text { か所のほか, 規模の小さい鉄穴場が多数存在し, } \\
\text { 確認しきない。 }\end{array}$ & 寛保 2 年「鉄山聞合セ書上帳」 & 脚注20） \\
\hline 延享 4 (1747)年 & $\begin{array}{l}\text { 備前国の公儀提訴により, 奥津・下齊原・上齊原村の鉄 } \\
\text { 穴流しは本年限り，上齊原・出・奥津川西村の鉄穴流 } \\
\text { しは宝暦 } 2 \text { 年までで差し止められることになった。** }\end{array}$ & 延享 4 年「作州鉄山之一件」 & 脚注51) \\
\hline 寛政 7 (1795)年 & $\begin{array}{l}\text { 上齊原 ·奥津・長藤・奥津川西村の鉄穴流しが差し止め } \\
\text { られ, 上齊原村では, 年貢の上納に行き詰まった住民の } \\
\text { 多くが離村するに至った。 }\end{array}$ & 文化 3 年「差上申済口証文之事」 & 脚注53） \\
\hline 享和 2 (1802)年 & $\begin{array}{l}\text { 村の困窮を理由に上齊原村は鉄穴流しの再開を認められ, } \\
\text { この年以降も下流の村々に冥加銀を支払いつつ鉄穴流し } \\
\text { を継続した。 }\end{array}$ & 文化 3 年「差上申済口証文之事」 & 脚注53） \\
\hline 文化元(1804)年 & $\begin{array}{l}\text { 上齊原・奥津・長藤・養野・箱村で計 } 7 \text { か所の鉄穴流し } \\
\text { が稼行され，下流の } 28 \text { か村との間に濁水紛争が発生した。 }\end{array}$ & 文化 2 年「差出申一札之事」 & 脚注52） \\
\hline 文化 $2(180$ & $\begin{array}{l}\text { 上齊原·奥津 ·長藤・養野 ·箱村における鉄穴流しの差 } \\
\text { し步めが決定したものの，上齊原村のみはこれに同意し } \\
\text { なかった。 }\end{array}$ & 文化 3 年「差上申済口証文之事」 & 脚注53） \\
\hline 文化 3 (1806)年 & $\begin{array}{l}\text { 前年の紛争にあたり，下流の水請村と上齊原村の間に合 } \\
\text { 意が成立し，上齊原村の鉄穴流しは差し止められた。 }\end{array}$ & $\begin{array}{l}\text { 文化 } 3 \text { 年「差上申済口証文之事」 } \\
\text { 文政 } 8 \text { 年「差上申鉄山稼熟証文之事」 }\end{array}$ & $\begin{array}{l}\text { 脚注53) } \\
\text { 脚注54) }\end{array}$ \\
\hline 文政 $3(1820)$ 年 & $\begin{array}{l}\text { 鉄穴流しを行う12か村と下流の28か村の間に「協定」が } \\
\text { 成立。被害の代償(銀礼20貫) を支払うことで，鉄 } \\
\text { 穴流しの10年間稼ぎか認可された。 }\end{array}$ & $\begin{array}{l}\text { 文政 } 3 \text { 年「差上申再熟談済口証文之 } \\
\text { 事」 }\end{array}$ & 脚注55） \\
\hline 文政 $8(182$ & $\begin{array}{l}\text { 鉄穴流しによる収入に対して, 年貢が賦課されているこ } \\
\text { とと,村の困筙を理由に，上齊原・下齊原村における鉄 } \\
\text { 穴流しの再開がみとめられ。 }\end{array}$ & 文政 8 年「差上申鉄山稼熟証文之事」 & 脚注54） \\
\hline 文政13(1830)年 & $\begin{array}{l}\text { 期限切れをむかえた文政 } 3 \text { 年の「協定」が } 3 \text { 年間延長さ } \\
\text { れた。 }\end{array}$ & 天保 5 年「差上申再熟談口証文之事」 & 脚注57） \\
\hline 天保 5 (1834)年 & $\begin{array}{l}\text { 下流33か村との「協定」にもとづいて, 稼ぎ村 } 7 \text { か村の } \\
\text { うち, } 1 \text { か所の鉄穴流しが弘化 } 2(1845) \text { 年まで認可され } \\
\text { た。 }\end{array}$ & 天保 5 年「差上申再熟談口証文之事」 & 脚注57） \\
\hline 弘化 4 (1847)年 & $\begin{array}{l}\text { 弘化 } 3 \text { 年以降も鉄穴流しが行われたため羽出村新古屋鉄 } \\
\text { 穴の襲撃事件が発生。 }\end{array}$ & 嘉永元年「乍恐以書付奉願上候」 & 脚注59） \\
\hline 嘉永 2 (1849)年 & $\begin{array}{l}7 \text { 村で } 2 \text { か所の鉄穴流し（上齊原村梅ノ木・杉小屋）が } \\
\text { 万延元年まで認可。 }\end{array}$ & 嘉永 2 年「熟談議定証文之事」 & 脚注58） \\
\hline 万延元 $(1860)$ 年 & $\begin{array}{l}7 \text { 村で } 2 \text { か所の鉄穴流し（奥津村水・庭うね）が元治元 } \\
\text { 年まで認可。 }\end{array}$ & 万延元年「濁水議定証文之事」 & 脚注58） \\
\hline 元治元(1864)年 & $\begin{array}{l}7 \text { 村で } 2 \text { か所の鉄穴流し（羽出村新古屋と奥津村庭う } \\
\text { ね）が慶応 } 4 \text { 年まで認可。 }\end{array}$ & 元治元年「濁水熟談議定証文之事」 & 脚注58） \\
\hline 慶応 4 (1868)年 & $\begin{array}{l}7 \text { 村で } 2 \text { か所の鉄穴流し（上齊原村木路・天王）が明治 } \\
5 \text { 年まで認可。 }\end{array}$ & 慶応 4 年「濁水熟談議定証文之事」 & 脚注58) \\
\hline
\end{tabular}

*上齊原村が 2 度にわたって鉄穴流しの差し止めを受けている理由については, 判然としない。

51）延享 4 年「覚」(津山市矢吹家文書)，前掲20）9頁。および前掲13）214頁。

52）前掲11）586頁。 
け入れなかった理由は，以下の史料によって知 ることができる。

（前略）当 [上齊原] 村鍬地鍛治稼之儀 者古来与冥加銀上納稼来当村之儀者夏作壱 毛作取村之方二而麦作与申者例年一向実法 不申至而土地覀敷故村方之米八上納米二者 年々不相成右稼故御年貢上納并村方相続仕 来候処先 [寛政 7] 年 (中略) [鉄穴流し を] 一旦差留メ二相成候得共迚茂相続難相 成御上納二差支手餘荒地出来家内引連立 退候モノ多分出来一村退 $\square$ 歴然二付段々始 末御願申上猶又前々之通相稼候様御聞済之 上古来之通引続相稼其後当村方右早川八郎 左工門様御支配所二相成候而乇年季明之節 者定免切替願上願之通被仰付引続是汽相稼 候儀二而訴訟方二而彼是可差障筋決而無之 鉄砂稼名目之儀者去儿戌 [享和 2 ] 年御支 配御役所江相願御伺御下知済之趣 $タ$ 以被仰 渡是又冥加銀上納仕相稼（後略）

[ ] 内筆者注

すなわちつぎのことが判明する。

高冷一毛作地の上齊原村における農業の生産 性はきわめて低かった（下線部(1)）。そのため寛 政 7 （1795）年における鉄穴流しの差し止めは, 年貢の上納困難に起因する多くの離村者を生じ させた（下線部(2)）。そこで上齊原村側が要求し た結果，鉄穴流しの再開が認められ (下線部(3)), 享和 2（1802）年以降も「冥加銀」を上納しつ つ鉄穴流しが継続されてきた(下線部(4))。

上齊原村の鉄穴流しは，「夏作壱毛作取村」 であることなどが考慮された結果，濁水紛争が 発生しても，これまで継続されてきたのである。 しかし, 文化 3 年の紛争では, 上齊原村も, 鉄
穴流しの差し止めを受けざるを得なかった模様 である。

文政 $3 （ 1820 ）$ 年以降には，12の鉄穴稼ぎ村 と下流地域との間には, 鉄穴流しの稼行年数, 鉄穴場の数，濁水の賠償などに関する合意のも と，鉄穴流しの稼行が認可されている(第 8 図)。

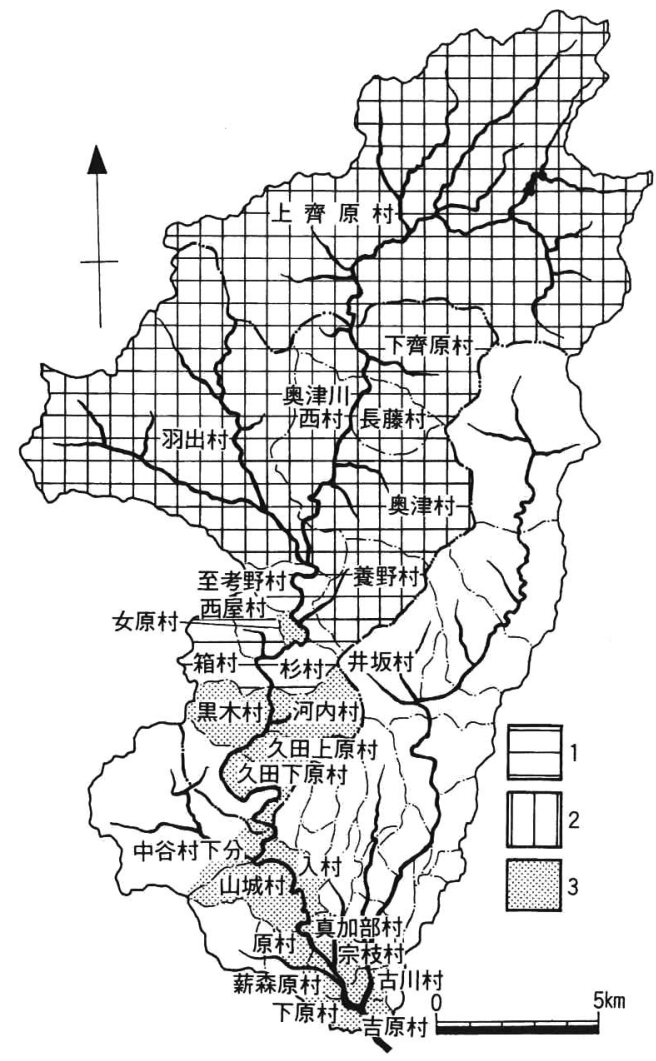

第 8 図 文政・天保期の鉄穴稼ぎ村と「協定」を 結んだ下流の藩政村

1. 文政 $3(1820)$ 年の「協定」締結時における鉄穴稼ぎ村 (12か村)

2. 天保 5 (1834) 年の「協定」締結時における鉄穴稼ぎ村 ( 7 か村)

3. 文政・天保期に鉄穴稼ぎ村と「協定」を結んだことのあ る下流の33か村（図に示されていない18か村は, 図の下流 に位置する。)

資料：脚注22）141頁，55），57）など。

53）文化 3 年「差上申済口證文之事」(鏡野町芳野小学校文書)，(宗森英之氏筆写提供史料)。

54）文政 8 年「上齊原村 下齊原村 差上申鉄山稼熟談証文之事」(岡山県川上村徳山家文書), (岡山県『岡山県史 第23 巻 美作家わけ文書』, 岡山県, 1989）1157-1158頁。

55）文政 3 年「差上申再熟談口証文之事」(上齊原村田渕家文書)。なおこの文書の一部については，つぎの文献に掲載され ている。前掲22）103頁。 
この認可にあたっても，「稼村々之儀者極山中 反作一毛取之村方二而例年麦作者一向生立不申, 冬春之稼無」, すなわち鉄穴稼ぎ村は水田単作 地域であり農間余業もないという点が考慮され ている。さらに文政 8 年にも，鉄穴流しに対し て年貢が賦課されている点を主張した上齊原村 と下齊原村は，鉄穴流し再開の認可を受けてい る。

文政 3 年に結ばれた協定にもとづく鉄穴流し は，明治期まで継続された。しかし，この協定 にもとづく鉄穴場の数は，きびしく制限されて いたといえる。天保 5 （1834）～弘化 2 (1845) 年には，12の鉄穴稼ぎ村のなかで，鉄穴場はわ ずか 1 か所に限定されている。ついで嘉永 2 （1849）年～明治 5 （1872）年には，７か村に減 少した鉄穴稼ぎ村のなかで，2 か所の鉄穴場が 認可されているにすぎない。この 7 か村は，上 齊原, 下齊原, 長藤, 奥津, 奥津川西, 養野, 羽出村といった吉井川上流域の北部，すなわち 脊梁山地に近いところに位置している(第 8 図)。 しかも，実際に鉄穴流しが稼行されたのは， 7 か村のなかでも脊梁山地にもっとも近い上齊原, 奥津, 羽出の 3 か村に限られる。この協定に違 反するようなことがあれば，弘化 4 (1847) 年 の事件のように，下流住民が鉄穴場を打ちこわ すべく鉄穴稼ぎ村へ押しかけることもあった。

このように，吉井川上流域の鉄穴流しは，農 民救済のために濁水紛争が生じても, 春梁山地 近くの村々を中心に稼行されてきた。しかしそ
の際，鉄穴場の数は，きびしく制限されること になった。当地域の最上流部に位置し, 高位小 起伏面および標高 $800 \mathrm{~m}$ 前後に発達する凹地状 の地形面は，上齊原杉小屋の事例で確認された ように（第 4 ・5図），1 か所の鉄穴場でより多 くの砂鉄採取が可能な地形条件にあるといえる。 鉄穴場の数がきびしく制限されていた時には, このような, 多量の砂鉄が 1 か所で効率よく採 取できる地点において，鉄穴流しが稼行される ことになったと思われる。実際に，嘉永 2 （1849）～万延元（1860）年にかけては，凹地状 の高位小起伏面にあたる上齊原杉小屋・梅ノ木 において，鉄穴流しが稼行されている。

さらに, 中国脊梁山地付近の最上流部におけ る鉄穴流しは，流出した土砂の河道への堆積や， 濁水の希䣋を促進するために，適しているよう に思われる。また，鉄穴流しにともなう廃砂は， 濁水の被害を軽減するために，人為的に河川沿 いの低地へ堆積されることも多かった。。その際， 高位小起伏面および標高 $800 \mathrm{~m}$ 前後に発達する 凹地状の地形面は, 廃砂を堆積させるのに適し た地形条件をそなえていたといえよゔ(第4 図)。 これらの点から, 春梁山地付近の村々で鉄穴流 しを行うことは，岡山藩との間に発生する濁水 紛争を防ぎたい津山藩にとっても，好都合であ ったと考えられる。春梁山地に近い最上流部に おいて鉄穴流しを行うことは，濁水紛争との関 連において，農民の救済とは別の利点ももって いたと考えられよう。

56）前掲54）1157頁。なお，前述したように，文政 3 年には鉄穴流しの稼行に関する協定が結ばれている。この状況におい て，文政 8 年に鉄穴流しの再開が認可されている点に関しては判然としない。

57 ) 天保 5 年「差上申熟談口証文之事」(上齊原村田渕家文書)。

58）嘉永 2 年「熟談議定之事」, 万延元年「濁水議定証文之事」, 元治元年「濁水熟談議定証文之事」, 慶応 4 年「濁水熟談 議定証文之事」(上齊原村田渕家文書)。および，前掲11）587-588頁。

59）嘉永元年「乍恐以書付奉願上候」(上齊原村田㴊家文書)。なおこの文書の一部については，つぎの文献に掲載されてい る。前揭22）143頁。

60) 前揭58)。

61) 前掲9) (2)695頁。

62）空中写真の判読や現地における地形調査によると，鉄穴流しの行われなかった凹地状の地形面に挄いて，一般に谷の埋 積はあまり進んでいない。しかし，凹地状の地形面に位置する鉄穴跡地の周辺には，埋積の進んだ浅い谷が少なからず確 認できる(第 4 図)。これらの谷は，鉄穴流しの廃砂による埋積の影響があらわれたものと思われる。 


\section{$\mathbf{V}$ む び}

本稿で明らかになったことを要約すると以下 のとおりである。

吉井川上流域の鉄穴跡地は, 吉井川の本流域 に全体（571.5 ha）の93.6\%（534.7 ha）が分布 し，香々美川ではみとめられない。鉄穴跡地の 集中する地域の地形は, 主として高位小起伏面 および標高 $800 \mathrm{~m}$ 前後の小起伏面と, 中位小起 伏面に属する山麓緩斜面である。調査対象地域 の北部に位置する上齊原村には全体の $63.3 \%$ (361.7 ha), 奥津村には $14.7 \%$ (83.8 ha) の鉄 穴跡地が分布している。鉄穴跡地の分布と地質 の関係をみると, 吉井川上流域の鉄穴跡地は花 崗閃緑岩よりも砂鉄含有量のいくぶん少ない黒 雲母花崗岩地域に多く分布している。

鉄穴流しや鑪製鉄への従事などによる収益は， 農民の生活にとって重要な役割をはたしていた ため, 濁水紛争の発生にともなう鉄穴流しの稼 行制限は，農民にとって大きな問題であった。 その結果, 高冷地ゆえに農業生産力の低位な上 齊原村や奥津村などでは，村方の救済を理由に， 鉄穴流しの稼行制限を受けることが少なかった。 また，近世末期において積極的な産鉄政策をと っていた津山藩にとっても, 最上流部に位置す る脊梁山地付近において鉄穴流しを行うことは, より多量の砂鉄生産をあげ，かつ岡山藩との濁 水紛争を防ぐために有利であったと考えられる。 したがって, 相対的に地質条件がやや悪い黒雲 母花崗岩の広がる北部の上齊原村や奥津村など に鉄穴場が集中した要因として, 高位小起伏面
という地形的条件に加えて，鉄穴流しの稼行制 限にみられた地域差が指摘できる。この稼行制 限をもたらしたのは，鉄穴流しの稼行にともな う濁水紛争であった。このように，人文条件と 地形・地質などの自然条件とをあわせることに よって，鉄穴跡地の立地移動が説明できるので ある。

濁水紛争に視点をあてつつ，鉄穴流しについ て研究を行うことは，ほかの地域においてもな されるべきである。今後の課題としては, (1)吉 井川上流域の鉄穴流しによる地形改変の規模や, 跡地における耕地化の実態などについて検討す ること，(2)鉄穴場の脊梁山地付近への集中が, 鑪製鉄の立地にいかなる影響を与えたのかにつ いて分析すること，などがあげられる。

[付記] 本稿は, 立命館大学文学部に提出した 1989年度卒業論文を加筆修正したものです。卒業 論文の作成にあたりましては，日下雅義教授（現 德島文理大学), 高橋学助教授, 本稿の作成にあ たりましては，戸所隆教授，河島一仁助教授をは じめとする立命館大学地理学教室の諸先生方にご 指導いただきました。現地調査ならびに史・資料 の収集にあたりましては，上齊原村役場土地対策 課の方々, 岡山県立津山高校の宗森英之先生, 岡 山県立博物館の田村啓介先生からご教示いただき ました。史料の一部につきましては，上齊原村教 育委員会の村誌編纂室が収集したものを利用させ ていただきました。空中写真の判読による鉄穴跡 地の認定にあたりましては, 北海道教育大学函館 分校の貞方昇先生にご指導いただきました。以上 の方々・機関に厚く御礼申し上げます。なお，本 稿の要旨は1990年度日本地理学会・春季学術大会 （会場 東京大学）に扔いて口頭発表いたしまし た。

Key words : iron sand mining (Kannanagashi), iron sand smelting method (Tatara), muddy water problem (Dakusui Funsō), Edo period, Yoshii River 